\title{
Reactivity of thyroid papillary carcinoma cells to thyroid stimulating hormone-dominated endocrine therapy
}

\author{
YUQIN MA, XIAZHANG and YUTAO WANG \\ Thyroid Disease Prevention and Control Center, Shandong Institute of Prevention and \\ Control for Endemic Disease, Jinan, Shandong 250014, P.R. China
}

Received July 3, 2017; Accepted October 6, 2017

DOI: $10.3892 / \mathrm{ol} .2017 .7173$

\begin{abstract}
This study investigated the effect of thyroid stimulating hormone (TSH) on the proliferation of papillary thyroid carcinoma (PTC) cells and the therapeutic effect of levothyroxine sodium (TH). PTC cells (TPC-1) were cultured using $0.1,1.0$ and $10 \mathrm{U} / 1 \mathrm{TSH}$ and $10^{-2}, 10^{-4}$ and $10^{-6} \mathrm{~mol} / 1$ TH. After the appropriate concentration was screened, TPC-1 cells were further divided into control group, TSH group, TH group and TSH+TH group. The cell proliferation was detected via methyl thiazolyl tetrazolium (MTT) method, TPC-1 cell cycle was detected via flow cytometer, and the mRNA and protein expression of cyclin D1 were detected via real-time polymerase chain reaction (PCR) and enzyme-linked immunosorbent assay (ELISA). Compared with control group, TSH significantly promoted the proliferation of TPC -1 cells $(\mathrm{P}<0.05$ or $\mathrm{P}<0.01)$, obviously promoted the transition of TPC-1 cells from $\mathrm{G} 1$ phase to $\mathrm{S}$ phase $(\mathrm{P}<0.01)$ and remarkably increased the mRNA and protein expression of cyclin D1 $(\mathrm{P}<0.01)$; but $\mathrm{TH}$ had a significant inhibitory effect on these results of TSH $(\mathrm{P}<0.05$ or $\mathrm{P}<0.01)$. TSH can promote the proliferation of PTC cells, and the appropriate complement of $\mathrm{TH}$ can inhibit its proliferation.
\end{abstract}

\section{Introduction}

Thyroid cancer is a kind of malignant endocrine system tumor with the highest incidence rate (1), which consists of 4 different pathological types: papillary thyroid carcinoma (PTC), medullary carcinoma, follicular carcinoma and undifferentiated carcinoma. Approximately 60-89\% of thyroid cancer is PTC (2) that is highly differentiated (3) and often occurs in children or female patients aged $20-50$ years. The

Correspondence to: Dr Yuqin Ma, Thyroid Disease Prevention and Control Center, Shandong Institute of Prevention and Control for Endemic Disease, 11 Yandong Xin Road, Jinan, Shandong 250014, P.R. China

E-mail: yuqin_masd@163.com

Key words: papillary thyroid carcinoma cell, thyroid stimulating hormone, thyroxine, cell proliferation, cyclin D1 pathogenesis of PTC is very complex, which is closely related to the heredity, environment and endocrine levels; moreover, the radioactive substances, Hashimoto thyroiditis and iodine deficiency can lead to the occurrence and development of PTC (4). In recent years, the incidence rate of PTC has risen continuously $(5,6)$, and it has aroused great concern of scholars world-wide. The combined application of treatment methods, such as surgery and nuclide, can significantly improve the survival of PTC patients, and the 10 -year survival rate of $70 \%$ patients can be up to 10 years (7). Thyroid stimulating hormone (TSH) receptor exists in PTC cells, and the PTC cell growth and differentiation depend on TSH secreted by pituitary gland to a certain extent. Therefore, the routine application of levothyroxine (TH) for TSH inhibition therapy after PTC operation can reduce the postoperative recurrence of patients and obtain a better prognosis (8). At the same time, the serum TSH level can be used as a clinical index of predicting PTC in patients with thyroid nodules $(9,10)$. In this study, the in vitro cell experiment was performed to observe the effects of TSH and TH intervention on the proliferation of PTC cells, and the role of TSH in the pathogenesis of PTC and the therapeutic effect of $\mathrm{TH}$ were investigated from the cytological level, so as to provide an experimental basis for the clinical prevention and treatment of PTC.

\section{Materials and methods}

Experimental materials and reagents. Human PTC cells (TPC-1) (BNCC, Beijing, China); cattle TSH and TH (Sigma, San Francisco, CA, USA); methyl thiazolyl tetrazolium (MTT) (Sigma); RPMI-1640 medium and fetal calf serum (Gibco, Grand Island, NY, USA); cell cycle assay kit (Beyotime, Shanghai, China); TRIzol RNA extraction reagent (Takara, Shiga, Japan); reverse transcription kit (Toyobo, Osaka, Japan); human cyclin D1 and $\beta$-actin primers (Shanghai Sangon Biomedical Engineering Co., Ltd., Shanghai, China); SYBR Green PCR Master mix (Takara); cyclin D1 enzymelinked immunosorbent assay (ELISA) kit (R\&D Systems, Inc., Minneapolis, MN, USA).

Laboratory equipment. $\mathrm{CO}_{2}$ incubator (Thermo Fisher Scientific, Inc., Waltham, MA, USA); clean bench (Suzhou Purification Equipment Co., Ltd., Suzhou, China); inverted fluorescence microscope (Nikon, Tokyo, Japan); flow 
Table I. Primer sequences.

\begin{tabular}{lcl}
\hline Detection gene & Amplification length & \multicolumn{1}{c}{ Primer sequence } \\
\hline Cyclin D1 & $146 \mathrm{bp}$ & Forward primer: 5'-CAATGACCCCGCACGATTTC-3' \\
& & Reverse primer: 5'-CATGGAGGGCGGATTGGAA-3' \\
$\beta$-actin & $200 \mathrm{bp}$ & Forward primer: 5'-CGCACCACTGGCATTGTCAT-3' \\
& & Reverse primer: 5'-TTCTCCTTGATGTCACGCAC-3' \\
\hline
\end{tabular}

cytometer (Becton-Dickinson, Franklin Lakes, NJ, USA); continuous-wavelength multi-function microplate reader (Tecan Austria, Grodig, Austria); real-time fluorescence quantitative polymerase chain reaction (PCR) instrument (Eppendorf, Hamburg, Germany).

TPC-1 cell culture. TPC-1 cells were cultured in RPMI-1640 medium containing $100 \mu \mathrm{g} / \mathrm{ml}$ streptomycin, $100 \mathrm{U} / \mathrm{ml}$ penicillin and $10 \%$ fetal bovine serum, and the liquid was replaced every other day, followed by passage after cells grew to $80 \%$ confluence. The 3-5-generation cells in the logarithmic growth phase were used for experiments.

Experimental grouping. 1) Single application of 0.1, 1.0 and $10 \mathrm{U} / 1 \mathrm{TSH}$; 2) single application of $10^{-2}, 10^{-4}$ and $10^{-6} \mathrm{~mol} / 1 \mathrm{TH}$; according to the appropriate concentration 1) and 2) screened in the early experiment, cells were further grouped and used for experiment: 1) Normal group: RPMI-1640 medium + 10\% fetal calf serum; 2) TSH group: 10U/1 TSH intervention; 3) TH group: $10^{-2} \mathrm{~mol} / 1 \mathrm{TH}$ intervention; 4) combined group: (TSH+TH group): $10 \mathrm{U} / 1 \mathrm{TSH}+10^{-2} \mathrm{~mol} / 1 \mathrm{TH}$ intervention. TPC-1 cells were treated in different culture solution for $48 \mathrm{~h}$. The study was approved by the Ethics Committee of Shandong Institute Hospital. Signed written informed consents were obtained from all participants before the study.

Detection of cell proliferation via MTT assay. TPC-1 cells were inoculated onto a 96-well plate with $10^{4}$ cells in each well. After the normal culture for $24 \mathrm{~h}$, the cells were synchronously incubated in the serum-free culture solution for $24 \mathrm{~h}$, and then $200 \mu \mathrm{l}$ different media were added for intervention for $48 \mathrm{~h}$ according to the above grouping. At the same time, the blank control group that was only added with complete medium without cells was set for zero setting. Six control wells were set for each group. After $48 \mathrm{~h}$, the original culture solution was removed from each well, and then $100 \mu 10.5 \mathrm{mg} / \mathrm{ml}$ MTT solution was added into each well for continuous incubation at $37^{\circ} \mathrm{C}$ for $4 \mathrm{~h}$. Then the MTT solution was absorbed, and $100 \mu$ l dimethyl sulfoxide was added into each well, followed by vibration on the shaking table to dissolve the crystal. The continuous-wavelength multi-function microplate reader was used to measure the optical density (OD) value at $492 \mathrm{~nm}$.

Detection of TPC-1 cell proliferation cycle. TPC-1 cells were inoculated onto a 6 -well plate with $10^{5}$ cells in each well. After normal culture for $24 \mathrm{~h}$, the control group, TSH group, $\mathrm{TH}$ group and $\mathrm{TSH}+\mathrm{TH}$ group received drug intervention for 48 h. Then cells were collected, pre-cooled using $75 \%$ alcohol at $-20^{\circ} \mathrm{C}$, and fixed overnight. Then cells were washed with phosphate buffered saline (PBS) 3 times, and then RNase and PI dye were added successively. Finally, the cell cycle in each group was measured using the flow cytometer, and the proportions of cells in G1 phase and S phase in each group were observed.

Total RNA extraction and reverse transcription. TPC-1 cells in control group, TSH group, TH group and TSH+TH group received the drug intervention for $48 \mathrm{~h}$. Then the cells were collected and added with appropriate amount of TRIzol reagent. The total RNA was extracted according to the instructions of TRIzol kit, and its concentration was determined using the ultraviolet spectrophotometer. Both RNA concentration and purity reached the experimental requirements. The cDNA was prepared via RNA reverse transcription according to the instructions and stored at $-80^{\circ} \mathrm{C}$.

Detection of mRNA expression level of cyclin D1 in each group via real-time PCR. The primer sequences of cyclin D1 and $\beta$-actin gene are shown in Table I. The reaction system was as follows: $2 \mu \mathrm{l}$ cDNA, $12.5 \mu \mathrm{l} 2 \mathrm{X}$ SYBR Green PCR master mixes, $0.5 \mu 1$ forward primer and $0.5 \mu 1$ reverse primer; finally ultra-pure water was added until the total volume was $25 \mu 1$. Amplification procedure: $95^{\circ} \mathrm{C}$ for $30 \mathrm{sec}, 95^{\circ} \mathrm{C}$ for $5 \mathrm{sec}$ and $60^{\circ} \mathrm{C}$ for $30 \mathrm{sec}$, a total of 40 cycles. After the amplification, the amplification curve and $\mathrm{Ct}$ value were read. With $\beta$-actin as a reference, the relative quantitative $2^{-\Delta \Delta C t}$ method was used to compare the expression difference of each gene.

Detection of cyclin D1 in TPC-1 cells. After the drug intervention for TPC-1 cells according to the above grouping for $48 \mathrm{~h}$, the supernatant was collected and centrifuged at $3,627 \mathrm{x}$ g for $10 \mathrm{~min}$ at $4^{\circ} \mathrm{C}$. The supernatant was separated for ELISA. Sample loading and treatment were performed strictly according to the instructions of the kit and the OD value was measured at $490 \mathrm{~nm}$ using the continuous-wavelength multi-function microplate reader. Besides, the standard curve was drawn and the content of cyclin D1 in each sample was calculated.

Statistical analysis. Experimental results are presented as mean \pm SD, and SPSS 20.0 software (IBM SPSS, Armonk, NY, USA) was used for statistical analysis of data. Independent sample t-test was used for the comparison between the two groups, one-way analysis of variance was used for the comparison among groups, and LSD method was used for the pairwise comparison. $\mathrm{P}<0.05$ is considered to indicate a statistically significant difference. 


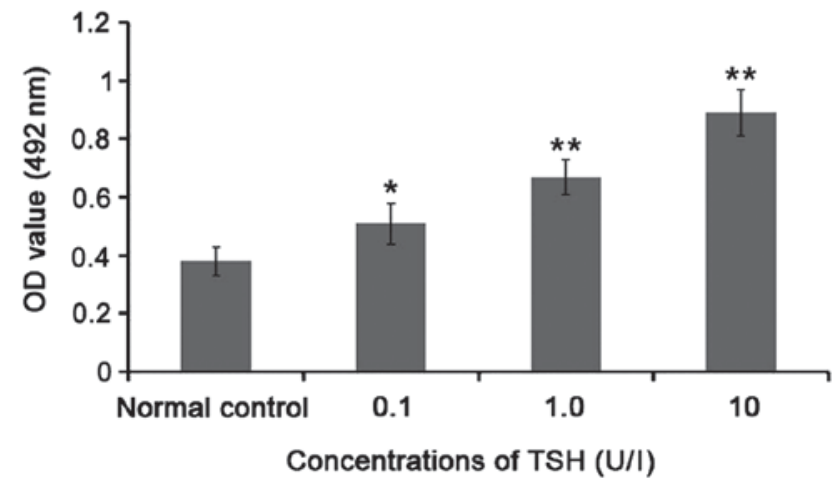

Figure 1. Effect of TSH on the proliferation of TPC-1 cells. MTT assay is used to detect the effects of different concentrations of TSH on the proliferation of TPC-1 cells, and the results show that the proliferation rate of TPC-1 cells is increased significantly with the increase in TSH concentration, compared with that in control group $(\mathrm{P}<0.05$ or $\mathrm{P}<0.01)$. ${ }^{*} \mathrm{P}<0.05,{ }^{* *} \mathrm{P}<0.01$ compared with normal group.

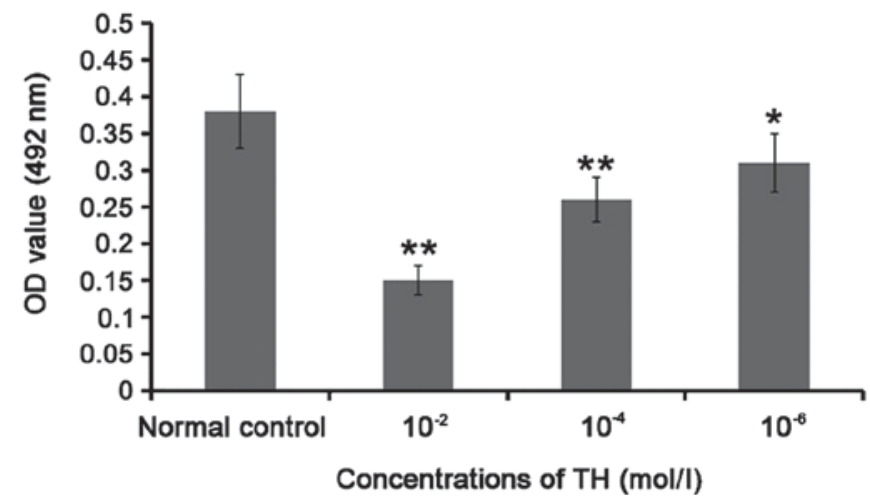

Figure 2. Effect of TH on the proliferation of TPC-1 cells. MTT assay is used to detect the effects of different concentrations of $\mathrm{TH}$ on the proliferation of TPC-1 cells, and the results show that the inhibition rate of TPC-1 cells is increased significantly with the increase in $\mathrm{TH}$ concentration, compared with that in control group $(\mathrm{P}<0.05$ or $\mathrm{P}<0.01)$. ${ }^{*} \mathrm{P}<0.05,{ }^{* *} \mathrm{P}<0.01$ compared with normal group.

\section{Results}

Effect of TSH on the proliferation of TPC-1 cells. Compared with that in normal control group, the OD value was significantly increased $(\mathrm{P}<0.05$ or $\mathrm{P}<0.01)$ after $0.1,1.0$ and $10 \mathrm{U} / 1$ TSH acted on TPC-1 cells for $48 \mathrm{~h}$; with the increase in TSH concentration, the OD value was significantly increased, suggesting that TSH can significantly promote the TPC-1 cell proliferation, and its proliferation reached the peak at $10 \mathrm{U} / 1$. Thus, $10 \mathrm{U} / 1 \mathrm{TSH}$ was selected for the subsequent experiments (Fig. 1).

Effect of TH on the proliferation of TPC-1 cells. Compared with that in normal control group, the OD value was significantly decreased $(\mathrm{P}<0.05$ or $\mathrm{P}<0.01)$ after $10^{-2}, 10^{-4}$ and $10^{-6} \mathrm{~mol} / 1 \mathrm{TH}$ acted on TPC-1 cells for $48 \mathrm{~h}$; with the increase in TH concentration, the OD value was significantly decreased, suggesting that TH can significantly inhibit the TPC-1 cell proliferation, and its proliferation reached the bottom at $10^{-2} \mathrm{~mol} / \mathrm{l}$. Thus, $10^{-2} \mathrm{~mol} / 1 \mathrm{TH}$ was selected for the subsequent experiments (Fig. 2).

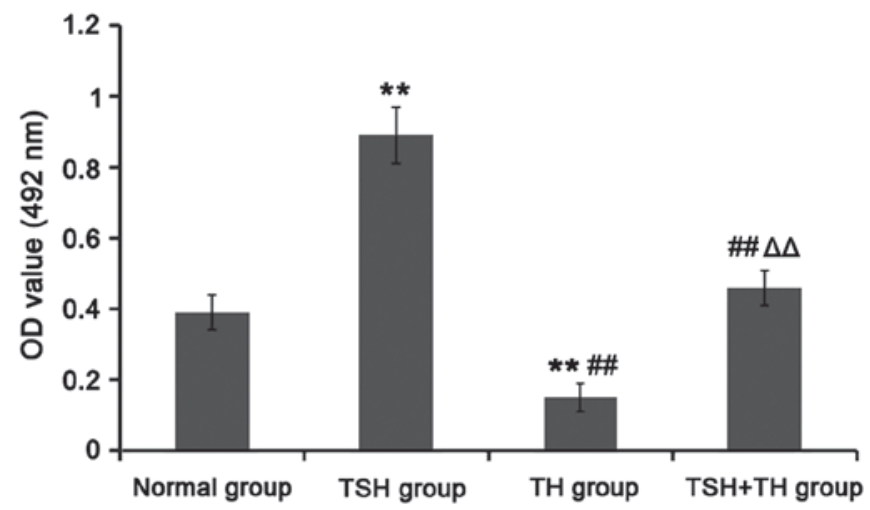

Figure 3. Effect of TH combined with TSH on the proliferation of TPC-1 cells. The cell proliferation in different groups was detected via MTT assay. The results show that TSH significantly promotes the proliferation of TPC-1 cells $(\mathrm{P}<0.01)$, while TH significantly inhibits the proliferation of TPC-1 cells, compared with control group $(\mathrm{P}<0.01)$. TH can significantly reduce the proliferation of TPC-1 cells $(\mathrm{P}<0.01){ }^{* * *} \mathrm{P}<0.01$ compared with normal group; ${ }^{\# \#} \mathrm{P}<0.01$ compared with TSH group; ${ }^{\triangle} \mathrm{P}<0.01$ compared with $\mathrm{TH}$ group.

Table II. Effects of TH, TSH and combined application on the mRNA and protein expression levels of cyclin D1.

\begin{tabular}{lll}
\hline Group & mRNA & Protein $(\mathrm{ng} / \mathrm{l})$ \\
\hline Normal group & $1.02 \pm 0.11$ & $1.89 \pm 0.25$ \\
TSH group & $2.18 \pm 0.34^{\mathrm{b}}$ & $3.07 \pm 0.38^{\mathrm{b}}$ \\
TH group & $0.63 \pm 0.20^{\mathrm{a}, \mathrm{d}}$ & $1.42 \pm 0.27^{\mathrm{a}, \mathrm{d}}$ \\
TSH+TH group & $1.32 \pm 0.32^{\mathrm{c}, \mathrm{e}}$ & $2.34 \pm 0.36^{\mathrm{c}, \mathrm{e}}$ \\
\hline
\end{tabular}

${ }^{\mathrm{a}} \mathrm{P}<0.05,{ }^{\mathrm{b}} \mathrm{P}<0.01$ compared with normal group; ${ }^{\mathrm{c}} \mathrm{P}<0.05,{ }^{\mathrm{d}} \mathrm{P}<0.01$ compared with TSH group; ${ }^{\mathrm{e}} \mathrm{P}<0.05$, compared with $\mathrm{TH}$ group.

Effect of TH combined with TSH on the proliferation of TPC-1 cells. Compared with that in normal group, the OD value was significantly increased in TSH group $(\mathrm{P}<0.01)$, but significantly decreased in $\mathrm{TH}$ group $(\mathrm{P}<0.01)$. Compared with that in TSH group, the OD values in $\mathrm{TH}$ group and $\mathrm{TSH}+\mathrm{TH}$ group were significantly decreased $(\mathrm{P}<0.01)$. The OD value in $\mathrm{TSH}+\mathrm{TH}$ group was significantly increased compared with that in $\mathrm{TH}$ group $(\mathrm{P}<0.01)$. There was no significant difference between $\mathrm{TSH}+\mathrm{TH}$ group and normal group $(\mathrm{P}>0.05)$. It can be seen that TH can significantly inhibit the proliferation of TPC-1 cells (Fig. 3).

Effects of TH, TSH and combined application on the TPC-1 cell cycle. Compared with those in normal group, the proportion of cells in G1 phase in TSH group was significantly decreased, but that in $\mathrm{S}$ phase was significantly increased $(\mathrm{P}<0.01)$; the proportion of cells in $\mathrm{G} 1$ phase in $\mathrm{TH}$ group was significantly increased, but that in $\mathrm{S}$ phase was significantly decreased $(\mathrm{P}<0.05)$. Compared with those in TSH group, the proportions of cells in G1 phase in TH group and TSH group were significantly increased, but those in $\mathrm{S}$ phase were significantly decreased $(\mathrm{P}<0.05$ or $\mathrm{P}<0.01)$. Compared with those in TH group, the proportion of cells in G1 phase in $\mathrm{TSH}+\mathrm{TH}$ group was significantly decreased, but that in $\mathrm{S}$ phase was significantly increased $(\mathrm{P}<0.05$ or $\mathrm{P}<0.01)$. There was no 


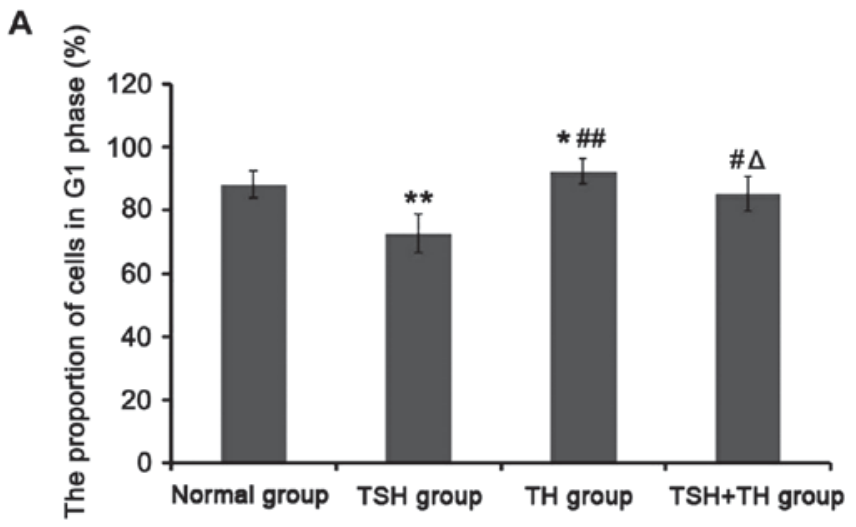

B

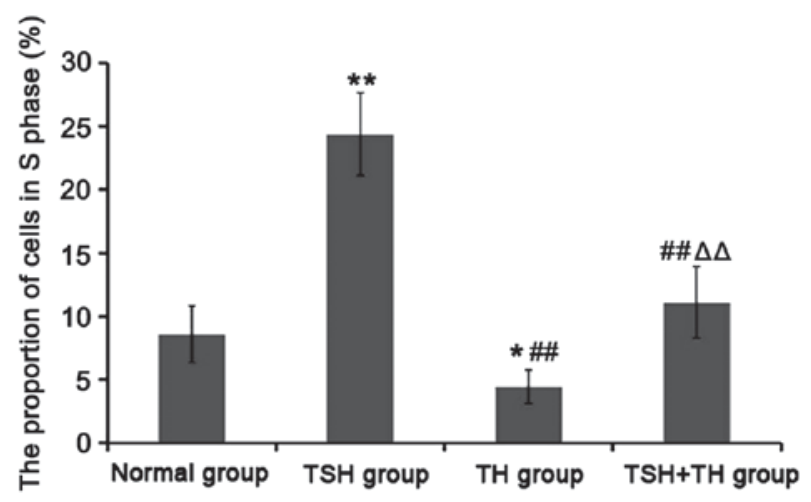

Figure 4. Effects of TH, TSH and combined application on the TPC-1 cell cycle. Flow cytometer was used to detect the cell cycle in each group. The results show that TSH significantly promotes the transition of TPC-1 cells from $\mathrm{G} 1$ phase to $\mathrm{S}$ phase $(\mathrm{P}<0.01)$, TH significantly inhibits the transition of TPC-1 cells from (A) G1 phase to $(B) S$ phase $(\mathrm{P}<0.05)$ and $\mathrm{TH}$ can significantly inhibit TSH from promoting the transition of TPC-1 cells from $\mathrm{G} 1$ phase to $\mathrm{S}$ phase $(\mathrm{P}<0.05$ or $\mathrm{P}<0.01)$. ${ }^{*} \mathrm{P}<0.05,{ }^{* * *} \mathrm{P}<0.01$ compared with normal group; ${ }^{\#} \mathrm{P}<0.05,{ }^{\# \#} \mathrm{P}<0.01$ compared with $\mathrm{TSH}$ group; ${ }^{\wedge} \mathrm{P}<0.05$, ${ }^{\triangle} \triangle \mathrm{P}<0.01$ compared with $\mathrm{TH}$ group.

significant difference between TSH+TH group and normal group ( $\mathrm{P}>0.05)$ (Fig. 4).

Effects of TH, TSH and combined application on the mRNA and protein expression levels of cyclin D1 in TPC-1 cells. Compared with those in normal group, the mRNA and protein expression levels of cyclin D1 in TSH group were significantly increased $(\mathrm{P}<0.01)$, and those in $\mathrm{TH}$ group were significantly decreased $(\mathrm{P}<0.05)$. Compared with those in TSH group, the mRNA and protein expression levels of cyclin D1 in TH group and TSH+TH group were significantly decreased $(\mathrm{P}<0.05$ or $\mathrm{P}<0.01)$. Compared with those in TH group, the mRNA and protein expression levels of cyclin D1 in $\mathrm{TSH}+\mathrm{TH}$ group were significantly increased $(\mathrm{P}<0.05)$. There was no significant difference between $\mathrm{TSH}+\mathrm{TH}$ group and normal group (P>0.05) (Table II).

\section{Discussion}

The largest endocrine gland in human body is the thyroid gland, and hypothalamus-anterior pituitary system regulates the growth, development and functions of thyroid gland (11). TSH is secreted by the anterior pituitary, its function is to promote the synthesis of thyroid hormone. Human TSH is a kind of glycoprotein in the body, mainly composed of 211 amino acids, $15 \%$ of which in the whole molecule is the sugar. Moreover, the entire TSH molecule consists of two peptide chains: $\alpha$ and $\beta$ chains. Moreover, the secretion of TSH has significant rhythm: TSH gradually increases at $2 \mathrm{~h}$ after sleep and its level in serum reach the peak at 2-4 o'clock in the morning $(12,13)$. TSH receptor belongs to the G-proteincoupled receptor, mainly expressed on the thyroid follicular epithelial cell membrane. The encoding gene of the TSH receptor is located on chromosome 14 and approximately $60 \mathrm{~kb}$ in length, which consists of 10 exons (14). TSH binds to the extracellular amino terminal of its receptor to regulate the thyroid function by enhancing the iodine pump activity and tyrosine iodination, promoting the thyroglobulin synthesis and enhancing the peroxidase activity (15).

In recent years, a large number of basic and clinical studies world-wide have found that when the thyroid hormone is lacking in the body, it can secrete a large amount of TSH into the blood, leading to high TSH and increasing the risk of thyroid tumor (16). Under the long-term stimulation of $\mathrm{TSH}$, thyroid tissues will suffer from diffuse enlargement, and the thyroid nodules are gradually formed with the course of disease, ultimately developing into thyroid cancer without timely treatment (17). In patients with thyroid nodules, the probability of suffering from thyroid cancer increases with the increase in serum TSH level (9). In animal experiments, it is found that the appropriate supplement of thyroxine can reduce the incidence of thyroid cancer (18).

PTC belongs to the thyroid cancer with a higher degree of differentiation. Compared with that in normal thyroid follicle cells, the TSH receptor transcription in PTC cells is reduced, but some functions are still retained. When TSH binds to its receptor, it can regulate the expression of thyroid peroxidase antibody, sodium/iodide symporter and other thyroid-specific genes through the adenosine cyclophosphate and other signaling pathways, while it can also regulate the thyroid cell proliferation and differentiation, ultimately accelerating the deterioration of PTC (19). Experimental studies have confirmed that the appropriate amount of TSH can promote the growth of thyroglobulin and thyroid cell proliferation (1), but the excessive increase in TSH can induce the PTC progression (20). After the PTC operation, the routine supplement of thyroxine can effectively inhibit the serum TSH level in the body and significantly reduce the recurrence and mortality rates of patients (21). It can be seen that the serum TSH level is closely related to the occurrence and progression of PTC, so reducing the serum TSH level can lower the incidence rate of PTC. In this study, the cell experiment proved that TSH can significantly promote the proliferation of PTC cells cultured in vitro, and the appropriate supplement of TH can inhibit its proliferation.

Cyclin D1 is a kind of important regulatory protein in G1 phase, and its encoded D1 protein plays an important role in regulating the transition from $\mathrm{G} 1$ phase to $\mathrm{S}$ phase. After D1 protein binds to cyclin-dependent kinase 4P6 (CDK4P6), the transcription and expression of a series of cell cyclerelated genes are induced, thus promoting the proliferation and differentiation of the cell cycle from G1 phase to S phase, which accelerates the whole cell cycle (22). Cyclin D1 is overexpressed in many malignant tumors of human, such as breast 
cancer and thyroid cancer $(22,23)$. In this study, it was also found that TSH can promote the mRNA and protein expressions of cyclin D1 in PTC cells, thus promoting the transition of cell cycle from $\mathrm{G} 1$ phase to $\mathrm{S}$ phase, which can be inhibited by the supplement of TH.

In conclusion, it was confirmed in this study through in vitro cell experiments that TSH can promote the proliferation of PTC cells, and the appropriate supplement of TH can inhibit its proliferation, providing an experimental basis for clinical medication. The occurrence and progression of PTC is a complex pathological process involving a variety of cell signaling pathways, and its relevant pathways need to be further studied.

\section{References}

1. van der Zwan JM, Mallone S, van Dijk B, Bielska-Lasota M, Otter R, Foschi R, Baudin E and Links TP; RARECARE WG: Carcinoma of endocrine organs: Results of the RARECARE project. Eur J Cancer 48: 1923-1931, 2012.

2. Liu TR, Su X, Qiu WS, Chen WC, Men QQ, Zou L, Li ZQ, Fu XY and Yang AK: Thyroid-stimulating hormone receptor affects metastasis and prognosis in papillary thyroid carcinoma. Eur Rev Med Pharmacol Sci 20: 3582-3591, 2016.

3. Ibitoye R and Wilkins A: Thyroid papillary carcinoma after alemtuzumab therapy for MS. J Neurol 261: 1828-1829, 2014

4. Min XS, Huang P, Liu X, Dong C, Jiang XL, Yuan ZT, Mao LF and Chang S: Bioinformatics analyses of significant prognostic risk markers for thyroid papillary carcinoma. Tumour Biol 36: $7457-7463,2015$

5. Ceresini G, Corcione L, Michiara M, Sgargi P, Teresi G, Gilli A, Usberti E, Silini E and Ceda GP: Thyroid cancer incidence by histological type and related variants in a mildly iodine-deficient area of Northern Italy, 1998 to 2009. Cancer 118: 5473-5480, 2012.

6. Zhang Z, Xu Z, Li Z, An C, Liu J, Zhu Y, Ni S, Tang P, Sayan A and Ilankovan V: Minimally-invasive endoscopically-assisted neck dissection for lateral cervical metastases of thyroid papillary carcinoma. Br J Oral Maxillofac Surg 52: 793-797, 2014.

7. Lee T, Cha YJ, Ahn S, Han J and Shim YM: A rare case of tumor-to-tumor metastasis of thyroid papillary carcinoma within a pulmonary adenocarcinoma. J Pathol Transl Med 49: 78-80, 2015.

8. Mazzaferri EL and Jhiang SM: Long-term impact of initial surgical and medical therapy on papillary and follicular thyroid cancer. Am J Med 97: 418-428, 1994.

9. Haymart MR, Repplinger DJ, Leverson GE, Elson DF, Sippel RS, Jaume JC and Chen H: Higher serum thyroid stimulating hormone level in thyroid nodule patients is associated with greater risks of differentiated thyroid cancer and advanced tumor stage. J Clin Endocrinol Metab 93: 809-814, 2008.
10. Fiore E, Rago T, Provenzale MA, Scutari M, Ugolini C, Basolo F, Di Coscio G, Berti P, Grasso L, Elisei R, et al: Lower levels of TSH are associated with a lower risk of papillary thyroid cancer in patients with thyroid nodular disease: Thyroid autonomy may play a protective role. Endocr Relat Cancer 16: 1251-1260, 2009

11. Medenica S, Nedeljkovic O, Radojevic N, Stojkovic M, Trbojevic B and Pajovic B: Thyroid dysfunction and thyroid autoimmunity in euthyroid women in achieving fertility. Eur Rev Med Pharmacol Sci 19: 977-987, 2015.

12. McNabb FM: Thyroid hormones, their activation, degradation and effects on metabolism. J Nutr 125 (Suppl): S1773-S1776, 1995.

13. Glinoer D: The regulation of thyroid function in pregnancy: Pathways of endocrine adaptation from physiology to pathology. Endocr Rev 18: 404-433, 1997.

14. Tomer Y, Barbesino G, Keddache M, Greenberg DA and Davies TF: Mapping of a major susceptibility locus for Graves' disease (GD-1) to chromosome 14q31. J Clin Endocrinol Metab 82: 1645-1648, 1997.

15. Gerschpacher M, Göbl C, Anderwald C, Gessl A and Krebs M: Thyrotropin serum concentrations in patients with papillary thyroid microcancers. Thyroid 20: 389-392, 2010.

16. Pacini F, Schlumberger M, Dralle H, Elisei R, Smit JW and Wiersinga W; European Thyroid Cancer Taskforce: European consensus for the management of patients with differentiated thyroid carcinoma of the follicular epithelium. Eur J Endocrinol 154: 787-803, 2006.

17. Pelizzo MR, Merante Boschin I, Toniato A, Pagetta C, Casal Ide E, Mian C and Rubello D: Diagnosis, treatment, prognostic factors and long-term outcome in papillary thyroid carcinoma. Minerva Endocrinol 33: 359-379, 2008.

18. Uruno T, Miyauchi A, Shimizu K, Tomoda C, Takamura Y, Ito Y, Miya A, Kobayashi K, Matsuzuka F, Amino N, et al: Favorable surgical results in 433 elderly patients with papillary thyroid cancer. World J Surg 29: 1497-1503, 2005.

19. Brabant G: Thyrotropin suppressive therapy in thyroid carcinoma: What are the targets? J Clin Endocrinol Metab 93: $1167-1169,2008$.

20. Sfakianakis GN, Skillman TG and George JM: Thyroxine withdrawal in thyroid cancer. Ohio State Med J 71: 79-82, 1975.

21. Kim SS, Lee BJ, Lee JC, Song SH, Kim BH, Son SM, Kim IJ, Kim YK and Kang YH: Preoperative serum thyroid stimulating hormone levels in well-differentiated thyroid carcinoma is a predictive factor for lateral lymph node metastasis as well as extrathyroidal extension in Korean patients: A single-center experience. Endocrine 39: 259-265, 2011.

22. Roy PG, Pratt N, Purdie CA, Baker L, Ashfield A, Quinlan P and Thompson AM: High CCND1 amplification identifies a group of poor prognosis women with estrogen receptor positive breast cancer. Int J Cancer 127: 355-360, 2010

23. Nakashima M, Meirmanov S, Naruke Y, Kondo H, Saenko V, Rogounovitch T, Shimizu-Yoshida Y, Takamura N, Namba H, Ito M, et al: Cyclin D1 overexpression in thyroid tumours from a radio-contaminated area and its correlation with Pin1 and aberrant $\beta$-catenin expression. J Pathol 202: 446-455, 2004. 